\title{
BILANČNÍ SRÁŽKO-ODTOKOVÝ HYDROLOGICKÝ MODEL V DENNÍM KROKU VÝPOČTU
}

\author{
LUMPED WATER BALANCE RAINFALL-RUNOFF MODEL WITHIN \\ A DAILY COMPUTATIONAL TIME STEP
}

Martin Bednáŕ ${ }^{*}$, Daniel Marton ${ }^{1}$

"bednar.mfce.vutbr.cz

${ }^{1}$ Vysoké učení technické v Brně, Fakulta stavební, Ústav vodního hospodářství krajiny, Žižkova 17, 60200 Brno

\begin{abstract}
Abstrakt
Hlavním cílem příspěvku je představení vyvíjeného softwaru představující bilanční srážko-odtokový hydrologický model. Software umožňuje uživateli vytvořit simulační model srážko-odtokového procesu v libovolném povodí, pro které jsou k dispozici potřebná měřená klimatologická a hydrologická data. Kalibrovaný model lze pak následně využít pro odhad odtoku vody z povodí na základě simulací výhledových klimatických vstupních dat, což umožní jistým způsobem analyzovat vliv klimatické změny na hydrologické podmínky v krajině. Model je vyvíjen a testován na části povodí řeky Dyje nad vodní nádrží Vranov.
\end{abstract}

\section{Klíčová slova}

Hydrologický model, simulace, lumped model, srážko-odtokový model, klimatická změna

\begin{abstract}
This paper aims to show the developed software representing a lumped water balance rainfall-runoff hydrological model. The software allows the user to create a simulation model of the rainfall-runoff process in any catchment for which the user can provide the necessary measured climatological and hydrological data. The calibrated model then can be used to predict runoff from the catchment based on the predicted input data, allowing for some analysis of the impact of climate change on hydrological conditions in the landscape. The model is developed and tested on a part of the Thaya river catchment, the part above the Vranov reservoir.
\end{abstract}

\section{Keywords}

Hydrological model, simulation, lumped model, rainfall-runoff model, climate change

\section{1 ÚVOD}

V současné době je změna klimatu velmi vážným tématem diskusí a její vliv na úplný klimatický systém je v současné době nezpochybnitelný [1]. Klimatická změna má zásadní dopad na přírodu, obyvatelstvo a vodní zdroje. Tyto dopady zaznamenáváme i na našem území, kdy sledujeme častější výskyt extrémního počasí a jeho následky [2]. Postupně jsou ovlivňovány především koloběh vody, což vede na změnu hydrologických podmínek $\mathrm{v}$ krajině. Takovéto změny jsou velmi nežádoucí z hlediska zásoby vody pro obyvatelstvo, jež jsou jednou z nejdůležitějších podmínek existence celé lidské populace. Je tedy důležité mít k dispozici nástroje pro odhad budoucího stavu klimatu a jeho vlivu na bilanci vody v krajině. Pomocí těchto nástrojů pak plánovat uskutečnění vhodných adaptačních opatření v dostatečném předstihu. Je zřejmé, že predikovat výskyt extrémních událostí ovlivňující vodní režim krajiny je obtížné. Je to dáno hlavně značnou mírou neurčitosti a nahodilosti, kterými jsou zatíženy srážka, a odtok vody z povodí. Avšak na základě sestrojených budoucích klimatických scénářu lze odhadnout jim odpovídající hydrologické podmínky $\mathrm{v}$ krajině. Nástrojem pro zjištění vazby mezi klimatologickými a hydrologickými jevy jsou tzv. srážko-odtokové modely, které popisují transformaci srážek na odtok vody z povodí.

Modelování srážko-odtokového procesu je jednou ze základních vědních dovedností v oboru hydrologie. Na základě klimatologických a geografických informací jsme schopni predikovat množství vody v povodí, resp. průtoky ve vodních tocích. Simulace srážko-odtokového procesu v povodí může napomoci lepšímu hospodaření s vodou, lepší manipulace se zásobními a retenčními objemy vodních nádrží nebo také snazší adaptaci na současné nebo budoucí klimatické podmínky. 
Cílem příspěvku je představení vyvíjeného softwaru představující srážko-odtokový model, který bude sloužit jako nástroj zpracování a převedení simulovaných klimatických scénářů na hydrologické veličiny v povodí. Software postupně provede uživatele jednotlivými fázemi př́pravy dat, volby výpočtových metod, nastavení optimalizační metody pro kalibraci modelu a následně výpočtu odtoku z povodí pro predikovaná, respektive simulovaná klimatologická vstupní data. V článku jsou představeny a popsány základní výpočetní kroky, které software umožňuje.

\section{POPIS SOUČASNÉHO STAVU}

Srážko-odtokové modely představují zjednodušení komplikovaných procesů, během kterých dochází $\mathrm{k}$ transformaci srážky na odtok vody z povodí (podzemní i povrchový), evapotranspiraci a infiltraci vody do půdy. Tyto procesy jsou ovlivněny mnoha činiteli, které definují geografické a klimatické vlastnosti v povodí. Právě tyto interakce mezi jednotlivými činiteli vymezují hranice využití hydrologických modelů, protože není z praktického hlediska možné získat potřebná data $\mathrm{v}$ každém bodě a čase např́ič celým povodím a definovat tak skutečnou povahu daných činitelů v povodí. Dle př́ístupu k definování interakcí mezi jednotlivými činiteli povodí existuje celá řada hydrologických modelů. Základní dělení srážko-odtokových modelů lze definovat třemi typy, a to: empirické modely, koncepční modely a fyzikální modely.

Empirické modely představují nejjednodušší formu srážko-odtokových modelů. Představují nelineární vztah mezi vstupními a výstupními daty. Tyto modely se označují jako tzv. „black box“ (,černá skř́ŕňka“) modely, protože veškeré procesy probíhají v rámci transformace srážky na odtok nelze ovlivnit a probíhají uvnitř modelu. Jedná se např́iklad o výpočty pomocí neuronových sítí nebo stanovení odtoku z povodí metodou CN křivek. Koncepční modely pak představují zjednodušené rovnice, které vyjadřují množství vody v povodí. Mezi takovéto modely patři Hydrologiska Byrans Vattenbalansavdelning (HBV) model vyvíjený švédským meteorologickým a hydrologickým institutem od počátku 70. let 20. století [3]. Fyzikální modely se pak řadí ke komplexní modelům. Výpočty charakterizující fyzikální zákony založené na reálné hydrologické odezvě povodí na srážku. Hojně využívaným fyzikálním modelem je MIKE System Hydrologique European (MIKE-SHE) od dánské firmy Danish Hydraulic Institute [4]. Dále lze modely třídit dle prostorového rozlišení, typu vstupních a výstupní dat, složitosti modelu apod. Důležitým dělením modelů je dělení dle prostorové interpretace vlastností povodí. Prostorová interpretace představuje, jakým způsobem se vlastnosti povodí extrapolují např́ic celým povodím s ohledem na měřená data. Tento př́stup rozlišuje modely celistvé (lumped), semi-distribuční (semi-distributed) a distribuční modely (distributed). Celistvé modely ignorují prostorovou variabilitu činitelů povodí a modelují srážko-odtokový proces na celém povodí jako celku. Veškeré veličiny se tedy průměrují na celou plochu povodí. Do skupiny celistvých modelů patř́ empirické modely. Distribuční modely již uvažují s prostorovou variabilitou parametrů povodí a veškerá data potřebná $\mathrm{k}$ výpočtu jsou specifikována na tzv. gridu (mř́̌žce). Každá buňka této mřížky má pak definované vlastnosti a výpočetní procesy. Jedná se o komplexní výpočty představující fyzikální model. Jistou přechodnou úrovní mezi celistvými a distribučními modely jsou tzv. semi-distribuční modely. Jedná se o řadu celistvých modelů, která mezi sebou interagují. Povodí je tedy rozděleno na části, na kterých se dané vlastnosti a veličiny průměrují a tyto úseky se počítají jako celistvé. Dohromady pak tvoří systém celistvých modelů definující procesy v celém povodí. Příkladem těchto modelů je TOPMODEL [5] nebo SWAT [6]. Volba vhodného typu modelu záleží především na účelu využití tohoto modelu a do jaké míry jsme schopni popsat vlastnosti v povodí, na kterém chceme modelovat srážko-odtokový proces.

\section{METODIKA}

Vytvořený software představuje bilanční srážko-odtokový hydrologický model, který je vytvořen jako celistvý. Veškeré parametry a sledované veličiny jsou tedy průměrovány na celé povodí. Model je založen na matematických rovnicích, které specifikují celkový denní odtok, denní nasycení půdy a denní evapotranspiraci v povodí. Vodní bilance je definována jako součet průměrného denního povrchového odtoku $q_{\mathrm{s}}$ a průměrného denního podzemního odtoku $q_{\mathrm{g}}$ a následné odečtení průměrné denní evapotranspirace $E_{\mathrm{p}}$. Rovnice představující srážko-odtokový proces v povodí jsou popsány v publikacích [7], [8]. Marton a Knoppová provedli úpravu zmíněných rovnic pro hydrologické a klimatické podmínky pro Střední Evropu [9]. Zmíněné rovnice byly původně sestrojené pro měsíční krok výpočtu. Software však přináší možnost využít jejich potenciál i v denním kroku výpočtu. Použité základní rovnice definující srážko-odtokový proces jsou popsány následovně:

$$
q_{s, i}=k_{s} \cdot \frac{s_{i-1}}{s_{\max }} \cdot h_{s, i},
$$


kde $q_{\mathrm{s}, \mathrm{i}}$ je průměrný denní povrchový odtok [mm], $k_{\mathrm{s}}$ je parametr modelu pro povrchový odtok [-], $S_{\mathrm{i}-1}$ je průměrná denní nasycenost půdy v předchozím kroku výpočtu [mm], $S_{\max }$ je maximální nasycení půdy [mm] a $h_{\mathrm{s}, \mathrm{i}}$ je průměrný denní úhrn srážek v povodí [mm]. Rovnice (2) popisuje výpočet podzemního odtoku $q_{\mathrm{g}, \mathrm{i}}$ :

$$
q_{g, i}=k_{g} \cdot S_{i-1}
$$

kde $q_{\mathrm{g}, \mathrm{i}}$ je průměrný denní podzemní odtok [mm], a $k_{\mathrm{g}}$ je parametr model pro podzemní odtok [-]. Následně je proveden výpočet průměrné denní evapotranspirace $E_{\mathrm{i}}$ pomocí rovnice (3):

$$
E_{i}=k_{e} \cdot \frac{s_{i-1}}{s_{\max }} \cdot E_{p, i}
$$

kde $E_{\mathrm{i}}$ je průměrná denní evapotranspirace z povodí [mm], $k_{\mathrm{e}}$ je parametr modelu pro evapotranspiraci [-], a $E_{\mathrm{p}, \mathrm{i}}$ je potenciální průměrná denní evapotranspirace $[\mathrm{mm}]$. Software aktuálně umožňuje využít jedné ze čtyř metod pro výpočet potenciální evapotranspirace. Metody výpočtu jsou založené na průběhu denních teplot. Konkrétně se jedná o metody Hargreaves [10], Turc [11], Thornthwaite [12] a Blaney-Criddle [13].

Celkový odtok vody z povodí $q_{\mathrm{c}, \mathrm{i}}$ je následně spočíán jako součet povrchového $q_{\mathrm{s}, \mathrm{i}}$ a podzemního odtoku $q_{\mathrm{g}, \mathrm{i}}$ :

$$
q_{c, i}=q_{s, i}+q_{g, i} .
$$

Nasycení půdy v povodí je stanoveno na základě rovnice (5):

$$
S_{i}=S_{i-1}+h_{s, i}-q_{c, i}-E_{i},
$$

kde $S_{\mathrm{i}}$ je průměrné nasycení půdy v povodí na konci $i$-tého dne výpočtu [mm], $S_{\mathrm{i}-1}$ je průměrné nasycení půdy $\mathrm{v}$ předchozím kroku výpočtu $[\mathrm{mm}], h_{\mathrm{s}, \mathrm{i}}$ je průměrný denní úhrn srážek v povodí $[\mathrm{mm}], q_{\mathrm{c}, \mathrm{i}}$ je průměrný denní celkový odtok vody z povodí [mm], a $E_{\mathrm{i}}$ je průměrná denní evapotranspirace z povodí [mm]. Rovnice (1) až (5) jsou řešeny pro $i=1,2, \ldots, n$, kde $n$ je délka časové řady vstupující do modelu.

\section{Optimalizace parametrů modelu}

Optimalizace parametrů modelu je zprostředkována pomocí algoritmu diferenciální evoluce. Po stanovení délky kalibračního a validačního období uživatel zvolí nastavení optimalizace parametrů modelu, kde lze každému z parametrů modelu lze nastavit interval hodnot představující meze, ve kterých bude hledána optimální hodnota těchto parametrů. Následně uživatel vybere jednu ze tří kriteriálních funkcí, dle kterých se parametry budou optimalizovat. Zde je na výběr ze tří funkcí. Konkrétně se jedná o kritérium Nash-Sutcliffe [14], střední kvadratickou chybu a střední kvadratickou odchylku. Následně uživatel zvolí rozsah dní (počet dní v roce), během kterých jsou parametry konstantní. Např́iklad pro hodnotu rozsahu 7, budou parametry konstantní po každých sedm dní, čímž se získá 53 parametrů v jednom roce pro každou výpočetní rovnici. Uživateli je rovněž zpř́stupněno nastavení samotného algoritmu. Zde si uživatel může měnit mutační konstantu, práh křížení, počet generací a velikost populace.

\section{VÝSLEDKY}

Uživatelské rozhraní software je vytvořeno tak, aby uživatel postupně nahrával potřebná data a postupně prováděl výpočty pro př́pravu vstupních hodnot do modelu. Postupné provádění výpočtů je zajištěno pomocí záložek, kterými se uživatel pohybuje v rozhraní softwaru.

\section{Vstupní data}

Na první záložce uživatel prostřednictvím dialogového okna průzkumníka Windows nahraje připravená vstupní data do softwaru. Vstupní data jsou rozděleny na čtyři soubory typu MS Excel. Každý soubor představuje jednu sledovanou veličinu na povodí, které jsou potřebné k simulaci. První soubor obsahuje časovou řadu denních minimální, maximální a průměrných teplot, druhý časovou řadu denních průměrných srážkových úhrnů, tř̌tí měřené odtoky v závěrovém profilu povodí a poslední soubor obsahuje seznam srážkoměrných stanic s uvedenými souřadnicemi polohy XYZ. V př́ípadě využití dat z více stanic jsou vstupní soubory upraveny tak, aby data z jedné stanice byly vždy na jednom listu sešitu v excelovském souboru. Následně musí uživatel znát plochu povodí v km², kterou rovněž zadává na záložce "Input data". Ve spodní polovině této záložky uživatel vybere z načtených stanic takové, které mu definují průměrnou polohu povodí (s ohledem na zeměpisnou šířku). Tento údaj je potřebný pro správné vyhodnocení některých evapotranspiračních metod. 


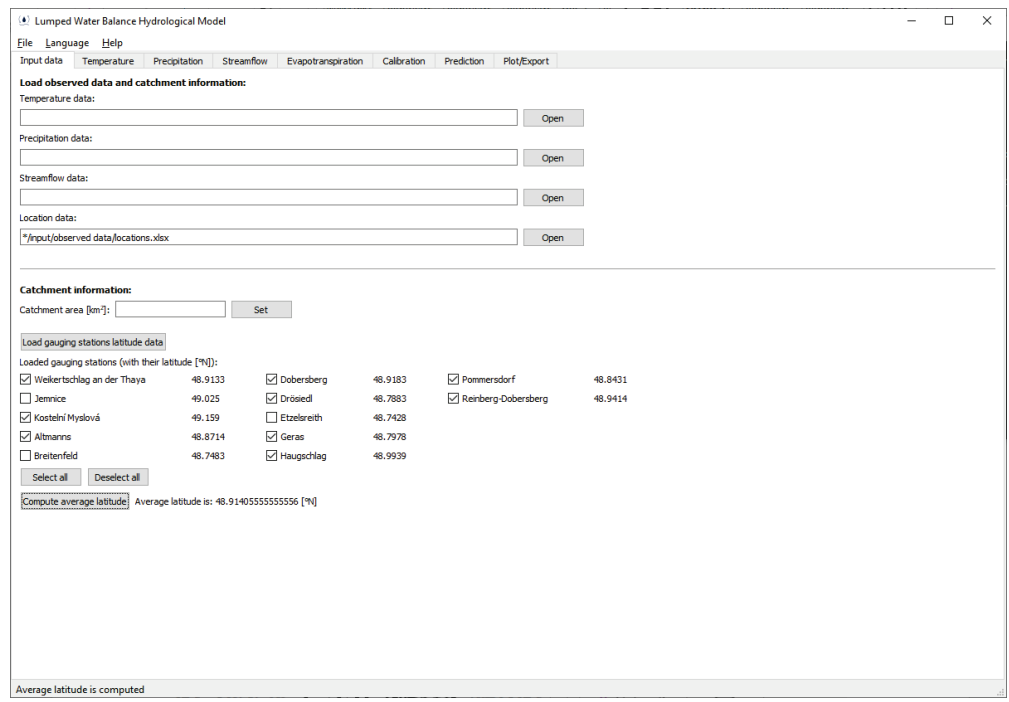

Obr. 1 Uživatelské rozhraní záložky "Input data" pro nahrání souborů obsahující vstupní data do modelu, ukázka výpočtu průměrné polohy v povodí.

\section{Př́íprava vstupních hodnot pro výpočet}

Nahrané vstupní soubory obsahují měřená data ze srážkoměrných stanic. Jelikož model představuje celistvý bilanční model, je třeba tyto data nejdříve zprůměrovat na celé povodí. K tomu slouží záložky "Temperature", "Precipitation" a "Streamflow". Tyto záložky postupně uživatele provedou přes zpracování dat teploty, srážkových úhrnů a měřených odtoků v závěrovém profilu. Na každé z těchto záložek software umožňuje uživateli graficky procházet vstupní (klimatologická a hydrologická) data z klimatologických a srážkoměrných stanic a hydrologických profilů. Subjektivní volbou může uživatel vybrat, ze kterých stanic budou měřená data použita, resp. zprůměrována pro další výpočty.

\section{Volba metody výpočtu potenciální evapotranspirace}

Na záložce "Evapotranspiration" jsou uživateli představeny průměrné denní potenciální evapotranspirace vypočtené jednotlivými dostupnými metodami. Pro výběr vhodné metody může uživatel zadat referenční potenciální evapotranspiraci pro zadané povodí a vykreslit si její průběh. Na základě toho může uživatel subjektivně porovnat referenční hodnoty s vypočtenými a následně zvolit nejvhodnější metodu. Grafické rozložení této záložky je znázorněno na Obr. 2.

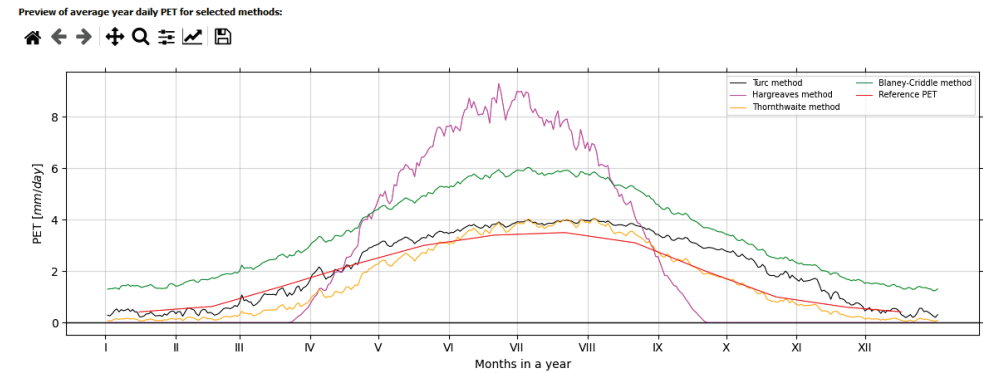

Obr. 2 Grafické zobrazení průměrných denních hodnot evapotranspirace na záložce "Evapotranspiration" pro výběr metody výpočtu potenciální evapotranspirace. 


\section{Kalibrace a validace modelu}

Záložka "Calibration" slouží k optimalizaci jednotlivých parametrů modelu. V první sekci uživatel zvolí délku kalibračního a validačního období na základě datumů počátku a konce těchto období. Software vyhodnotí délku těchto období a vypíše uživateli v jakém poměru jsou tato období z hlediska objemu dat. Následně uživatel vybere kriteriální funkci a zvolí délku rozsahu parametrů (viz kapitola Optimalizace parametrů). Dále před spuštěním kalibrace je uživateli k dispozici nastavení intervalů jednotlivých parametrů a optimalizačního algoritmu.

\section{Simulace odtoku vody z povodí}

Záložka "Prediction" slouží k výpočtům odtoků vody z povodí na základě jiných vstupních dat než kalibračních a validačních. Záložka má identický vzhled jako záložka "Input data". Slouží pro načtení nových dat obsahující klimatologická a hydrologická data pro vybrané povodí, na které je model nakalibrovaný a následný výpočet průměrných denních odtoků vody z povodí.

\section{DISKUZE}

Model se vyvíjel a testoval na části povodí řeky Dyje, která představuje sběrnou plochu nad vodní nádrží Vranov. Plocha vybraného povodí je $2124.2 \mathrm{~km}^{2}$. Pro kalibraci modelu pro toto povodí bylo využito třech meteorologických stanic měřících teplotu, dvanácti srážkoměrných stanic a dvou hydrologických profilů. Model byl zatím kalibrován pouze dle kriteriální funkce Nash-Sutcliffe (NSE) a pro metodu evapotranspirace dle Turce. Období konstantních parametrů bylo voleno v rozsahu jednoho až sedmi dní. Pro tyto nastavení dosáhlo kalibrační kritérium NSE v každém př́ípadě hodnoty více jak 0.6. Dle [15] tato hodnota představuje uspokojivý hydrologický model.

Z výsledků však bylo patrné, že model ne prríliš přesně modeluje odtoky v zimních obdobích. Dále v testech vlivu volby intervalu mezí jednotlivých parametrů se projevila vysoká citlivost modelu na tyto rozsahy. Výsledky byly výrazně ovlivněny především změnou rozsahů pro parametr evapotranspirace. Z těchto poznatků je zř̉ejmé, že model potřebuje další testování na dalších povodích různých typů a sledovat změny chování modelu na těchto povodích.

\section{ZÁVĚR}

Vyvíjený software představující bilanční srážko-odtokový model prokázal funkčnost použitých metod. Jedná se prozatím však pouze o verzi 1.0. Zdrojový kód je napsán prostřednictvím programovacího jazyka Python 3 obecným způsobem tak, aby nebyl uživatel prŕliš omezen formátem vstupních dat do modelu. Ačkoliv je model kategorizován jako uspokojivý, použití modelu poukázalo také na jeho citlivost ve volbě rozsahů výskytu jednotlivých parametrů. Nejvíce citlivé se ukázaly být volené meze pro parametry evapotranspirace. Dále z hlediska kalibrace a validace modelu je vhodné v budoucnu přidat více kriteriálních funkcí, jako jsou např́klad koeficient determinace $\left(\mathrm{R}^{2}\right)$, poměr směrodatné odchylky a střední kvadratické odchylky (RSR), procentuální BIAS (PBIAS) a index shody (d).

Výsledky z aplikace modelu na část povodí řeky Dyje prokázaly, že při přechodu z měsíčního kroku výpočtu na denní se daná problematika modelování srážko-odtokového procesu patřičně zkomplikovala. Např́iklad bude nutné přidat do modelu i výpočet tání sněhové pokrývky. Z výsledků totiž bylo patrné, že v zimních obdobích jsou modelované odtoky výrazně odlišné než skutečné. Což se mohlo projevit na hodnotách výsledných optimalizačních kritérií v kalibračním a validačním období. Jelikož se v denním kroku výpočtu může podzemní odtok projevit více než při měsíčním kroku, bude nutno přidat i možnost zpoždění podzemního odtoku v rámci odezvy na srážku v povodí. Software bude v budoucnu využit pro analýzu srážko-odtokového procesu na vybraných povodích a při jeho využívání bude rovněž testován a doplňován o patřičné výpočetní moduly, příp. o doporučení volby nastavení modelu pro dané typy povodí.

\section{Poděkování}

Tento příspěvek je výsledkem specifického výzkumu FAST-J-21-7371 „Nástroje pro zvládání klimatické změny a zajištění udržitelného rozvoje ve vodním hospodářství krajiny“. 


\section{Použité zdroje}

[1] IPCC. Climate Change 2021: The Physical Science Basis. Contribution of Working Group I to the Sixth Assessment Report of the Intergovernmental Panel on Climate Change. Cambridge University Press. 2021.

[2] MŽP. Strategie přizpůsobení se změně klimatu v podmínkách ČR. Dostupné [online]. 2015, [cit. 202111-05]. Dostupné z:

https://www.mzp.cz/C1257458002F0DC7/cz/zmena_klimatu_adaptacni_strategie/\$FILE/OEOK_Nar odni_adaptacni_strategie-aktualizace_20212610.pdf

[3] DEVIA, Gayathri K., B.P. GANASRI a G.S. DWARAKISH. A Review on Hydrological Models. Aquatic Procedia [online]. 2015, 4, 1001-1007 [cit. 2021-11-05]. ISSN 2214241X. Dostupné Z: doi:10.1016/j.aqpro.2015.02.126

[4] ABBOTT, Dallas H., Janet L. MORTON a Mark L. HOLMES. Heat flow measurements on a hydrothermally-active, slow-spreading ridge: The Escanaba Trough. Geophysical Research Letters [online]. 1986, 13(7), 678-680 [cit. 2021-11-05]. ISSN 00948276. Dostupné z: doi:10.1029/GL013i007p00678

[5] BEVEN, K. J., M. J. KIRKBY a G.S. DWARAKISH. A physically based, variable contributing area model of basin hydrology. Hydrological Sciences Bulletin [online]. 1979, 24(1), 43-69 [cit. 2021-1105]. ISSN 0303-6936. Dostupné z: doi:10.1080/02626667909491834

[6] ARNOLD, J. G., R. SRINIVASAN, R. S. MUTTIAH a J. R. WILLIAMS. LARGE AREA HYDROLOGIC MODELING AND ASSESSMENT PART I: MODEL DEVELOPMENT. Journal of the American Water Resources Association [online]. 1998, 34(1), 73-89 [cit. 2021-11-05]. ISSN 1093-474X. Dostupné z: doi:10.1111/j.1752-1688.1998.tb05961.x

[7] WANG, G.Q., J.Y. ZHANG, J.L. JIN, Y.L. LIU, R.M. HE, Z.X. BAO, C.S. LIU a Y. LI. Regional calibration of a water balance model for estimating stream flow in ungauged areas of the Yellow River Basin. Quaternary International [online]. 2014, 336, 65-72 [cit. 2021-11-05]. ISSN 10406182. Dostupné z: doi:10.1016/j.quaint.2013.08.051

[8] WANG, Guoqing, Jianyun ZHANG a Qinli YANG. Attribution of Runoff Change for the Xinshui River Catchment on the Loess Plateau of China in a Changing Environment. Water [online]. 2016, 8(6) [cit. 2021-11-05]. ISSN 2073-4441. Dostupné z: doi:10.3390/w8060267

[9] MARTON, D. a K. KNOPPOVÁ. Developing hydrological and reservoir models under deep uncertainty of climate change: robustness of water supply reservoir. Water Supply [online]. 2019, 19(8), 2222 2230 [cit. 2021-11-05]. ISSN 1606-9749. Dostupné z: doi:10.2166/ws.2019.102

[10] HARGREAVES, G. a Z. SAMANI. Reference Crop Evapotranspiration from Temperature. Applied Engineering in Agriculture [online]. 1985, 1(2), 96-99 [cit. 2021-11-05]. ISSN 1943-7838. Dostupné z: doi:10.13031/2013.26773

[11] TURC, L. Water requirements assessment of irriga- tion, potential evapotranspiration: Simplified and updated climatic formula. Annales Agronomiques. 1961, 12, 13-49.

[12] THORNTHWAITE, C. W. An Approach toward a Rational Classification of Climate. Geographical Review [online]. 1948, 38(1) [cit. 2021-11-05]. ISSN 00167428. Dostupné z: doi:10.2307/210739

[13] BLAYNEY HF, CRIDDLE WD. Determining consumptive use and irrigation water requirements. 1962, USDA Technical Bulletin 1275, US Department of Agriculture, Beltsville

[14] NASH, J.E. a J.V. SUTCLIFFE. River flow forecasting through conceptual models part I — A discussion of principles. Journal of Hydrology [online]. 1970, 10(3), 282-290 [cit. 2021-11-05]. ISSN 00221694. Dostupné z: doi:10.1016/0022-1694(70)90255-6

[15] Hydrologic and Water Quality Models: Performance Measures and Evaluation Criteria. Transactions of the ASABE [online]. 2015, 58(6), 1763-1785 [cit. 2021-11-05]. ISSN 21510032. Dostupné z: doi:10.13031/trans.58.10715 